\title{
Sustainable housing for sustainable cities: case study of Bucharest
}

\author{
E. Creanga, I. Budisteanu \& M. Duda \\ University Spiru Haret, Department of Architecture, Romania
}

\begin{abstract}
Housing accounts for the major part of a city's assets. Different perspectives on sustainable housing encompass technical, social, political and economic issues. Physical indicators are not enough to assess the overall quality of housing. Perceptions of sustainable housing have moved from individual dwellings to issues of community and neighbourhood. Romania is confronted with specific challenges in housing. Due to the wholesale privatisation of the early 1990s, Romania is a "country of homeowners" with over $97 \%$ of the housing stock in private ownership. Twenty years after the political changes, the country is still confronted with a wide range of housing sustainability issues: at the level of buildings with overdue maintenance and repair, energy use, raising running costs; at neighbourhood level with transportation, public space, dissatisfaction of residents; at city level, with the growing negative perception of certain neighbourhoods and the declining asset value of properties. In Bucharest, where over $80 \%$ of dwellings are situated in blocks of flats in large housing estates built after 1960, housing is largely at odds with the barriers that would make the housing environment liveable: economic, financial, institutional, perceptual, behavioural and, not least, the market. Government actions and certain community initiatives address the security of buildings, security of tenure, security of asset value. New construction is constrained by scarce free land within the city and a market that caters mainly for the upper income scale. Freedom of choice has been restricted so far to residential parks at the outskirts of the city and some condominiums scattered within its boundaries. The paper highlights recent trends and the envisaged longterm views for a sustainable development of Bucharest.
\end{abstract}

Keywords: home ownership, housing policy, housing quality, urban structure, social segregation, housing consumption patterns, urban development. 


\section{Introduction}

As the components of built environment are not mere urban forms but sites within which social, human, political and environment factors are intertwined, a whole range of issues need to be investigated. In all cities and metropolises the residential mosaic within the urban structure is the result of dynamic processes having major impacts on traditional urban structures, on community life, on infrastructure development and urban management. Bucharest, the capital city of Romania is no exception.

In this case study we analyse the transformations of the last two decades that generated new processes subject to reflection and investigation in an attempt to finding clues for the new model (models) of possible future development of the city.

\section{A short historic overview}

The development of a modern Bucharest started in the first half of the 19th century when the current structure of the city was laid out and explicit urban policies were devised (Lascu [1]). The development of the city over the next one hundred years - up to WWII - illustrates the role played by urban planning through its specific tools - master plans and building regulations - in shaping a modern city; part and parcel were the endeavours of the successive administrations to diversify what we call today housing options (including lowcost housing and incentives for moderate income families to accede to property). Bucharest assimilated the modern architecture of the 20th century which changed radically the urban landscape of the inner city. New land divisions on the periphery were turned into "quarters for workers or public officers". In the meantime the city absorbed a number of communes situated in its immediate proximity. By pre-WWII standards the capital city of Romania was already a metropolis and an urban agglomeration.

Urban development of the post-war years bore the characteristics of the centralized and planned economy. Planning principles induced considerable changes in the structure of the city and modified its relations with the surrounding territory. Pre-war housing construction based on individual plots and private property was replaced by large residential areas with multi-story multi-family blocks of flats, built in most cases of large prefab panels. Large housing estates became urban mega-structures.

Two more major events further modified considerably the actual urban landscape of Bucharest: the major earthquake of 1977 and the development of the mega-project known as the "New Civic Centre" in the 1980s. The latter including the large building that is now the Palace of Parliament changed dramatically the traditional urban structure.

This brief overview of the evolution of Bucharest over the last 150 years provides the image of a complex urban structure resulting from the historic stratification of the city. However, today's Bucharest has kept so far some of its 


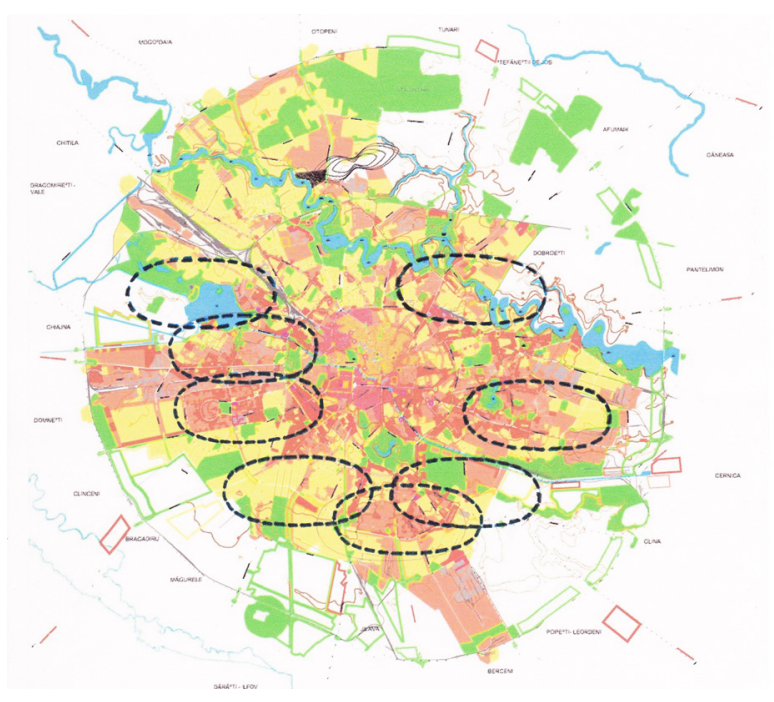

Figure 1: Major housing estates - over $80 \%$ of the city's population lived in blocks of flats at the last Census (2002).

monuments at human scale, its green areas, some specific characteristics of its public spaces - all of which are part of its identity and its cultural footprint.

\subsection{Changes in the last two decades}

Table 1: Evolution of the housing stock between the last two censuses.

\begin{tabular}{|c|c|c|}
\hline \hline & $\mathbf{2 0 0 2}$ & $\mathbf{1 9 9 2}$ \\
\hline \hline Population & $2,009,200$ & $2,065,700$ \\
\hline No of buildings & 113,364 & 109,125 \\
\hline No of permanent residences & 779,144 & 761,156 \\
\hline Average area/unit $-\mathrm{m}^{2}$ & 38.2 & 34.5 \\
\hline Average area/room $-\mathrm{m}^{2}$ & 15.9 & 14.5 \\
\hline Average area/person - $\mathrm{m}^{2}$ & $15.9^{*}$ & $13.0^{*}$ \\
\hline Average no of persons/ unit & 2.41 & 2.66 \\
\hline No of households & 734,084 & 742,628 \\
\hline Average no of persons./households & 2.55 & 2.72 \\
\hline \hline
\end{tabular}

The 1990s brought about major changes in housing aspirations and triggered a wide process of re-evaluation of the living environment. The major indicators of the housing stock in Bucharest improved slowly but steadily after 1990 (Table 1).

One of the major characteristic of the housing stock of the capital city remains the large share of multi-family blocks of flats - over $70 \%$. 


\subsection{Housing quality}

Although a number of local studies have been undertaken, the overall physical state of the housing stock in Bucharest has not yet been surveyed, and the cost of dealing with the need for repair, remodeling, refurbishment and renovation remains un-quantified (Lujanen [2]).

Furthermore, the challenge for housing appears to be compounded by the poor condition of the local physical infrastructure that services housing - for example, the utility services, including energy and water distribution, district heating systems, sewage and refuse collection.

Bucharest is facing the need for the restructuring and renewal of large estates of multistory apartment housing where management and maintenance have been inadequate and the long-term continued use of the buildings is in question. Neglected, these housing estates are likely to show increasing social problems to add to the physical and economic ones.

While not experiencing the same problems of shared responsibilities as the new owners of apartments in condominiums, the residents of older family houses do share the economic and financial limitations of those living in apartment blocks. Equally, although the physical condition of their homes tends to be better than that of apartment blocks, its maintenance and repair has been typically neglected for decades, and therefore also represents a major challenge. In short, additional investment into this sector of the housing stock is needed to avoid its further deterioration.

An additional problem for many residents in this stock is the threat of losing their home through claims for restitution by the former owners or their descendants.

\section{Housing policies and their impact on the urban structure}

Property structure and access to housing are the corner stones of any housing policy. Their change over time is an indication of the basic objectives of a housing policy (Kemeny [3]). Therefore, when analyzing housing policies of the past two decades we should take a long-term view that include spatial, economic and sociological considerations.

Housing policies of the last two decades were dominated by two major phenomena:

a) Massive privatization - Romania becoming a "super-homeownership" country (Tsenkova [4]); privatisation was followed by the accelerated decay of the privatized housing stock. Units in multi-family structures account for almost $80 \%$ of the total stock. Poor initial construction, long-deferred maintenance and repair has led to the rapid aging of the stock.

The large owner-occupied sector still displays a high level of immobility with most of the owner-occupiers captive in their privatized flats. Existing units keep losing their asset-value as reflected in the decreasing number of transactions on the secondary market (Budisteanu [5]), thus lowering supply in the existing stock and hampering housing mobility (Turner et al. [6]). Meanwhile the upward 
filtering of higher income families to new types of housing and new environments all but enhanced the difficulties of owner-occupiers to cope with the cost of rehabilitation and refurbishment of their condominiums. Social and spatial segregation are already visible in certain areas of the city.

The almost total transfer of the public stock to private ownership resulted in more than one distortion of the housing system. As authorities were left with a negligible residual public stock, they cannot meet the most urgent social demand nor provide alternative accommodation in cases of eviction or natural disasters. Almost twenty years later, homeowners and authorities are still looking for ways to cope with these consequences with a view to making homeownership sustainable.

However, privatization enabled the early development of a housing market and the emergence of a fluid real estate market (Budisteanu [5]), mainly in the existing stock. On the other hand, scarce free land for building in Bucharest made housing market outside Bucharest more attractive and accessible, both in terms of price and building formalities.

b) Affordability issues pervaded the whole housing sector. For most of the 1990, affordability issues were due to the macro-economic environment and the lack of housing finance. Low wages, high and volatile interest rates, the reluctance of banking institutions to issue long-term loans were factors that contributed to the late development of an active housing finance sector

Government policies and programs at national level were contradictory and strongly biased towards home-ownership. They relied on the received wisdom of a generally laissez-faire approach of the free market where housing supply and demand would adjust freely to meet various needs, without the intervention of the authorities and institutions (UN-ECE, 2000 [7]). Throughout the 1990s the major aim was to reduce the gap between market house prices and family incomes, especially by devising various measures that would enable young individuals and families to accede to homeownership.

The major government program was the creation of the National Housing Agency (NHA) in 1999 with the aim to boosting new housing construction and grant access to first-time buyers, especially young households. The early success of the NHA was due to lowering prices by providing serviced land leased free of charge for the life of the construction. Also, the NHA was the first institution to promote housing mortgage finance through selected banks.

As, by law, housing provision is the responsibility of the local government and a considerable share of the local budget is being dedicated to "housing related expenditure", i.e. winter subsidies for utility payments, building of general infrastructure etc. Direct housing support for specific programs: thermal insulation of blocks of flats, consolidation of the earthquake-damaged high-rise buildings. As of late a thermal rehabilitation of the blocks of flats is under waysupported by the central and local government - that would increase energy efficiency, while improving the outlook of the dilapidated facades.

Direct investment in public rental and social housing was at a very low level up to now. However, the issue of public housing became topical over the last years due to the growing number of evictions after the restitution of buildings to 
former owners. Affordability issues were most acute for the younger generation that did not benefit of the wholesale privatization and was left out in the cold.

\subsection{Changes in the urban structure}

A careful reading of the territorial distribution of urban housing - in the particular case of Bucharest - highlights the relationships between the overall economic-social-institutional framework and the changes in the housing system.

Urban development conditions changed dramatically after 1990s, namely:

- transformation of the city's economy - the decline of major manufacturing industries, changes in the occupational structure of the population;

- radical changes in the housing system - privatization, the emergence of a large category of homeowners, lifting of restrictions on multiplehomeownership;

- social polarization

- decentralization and the increasing autonomy of local governments;

- $\quad$ the relatively rapid development of a housing market.

Yet, the traditional urban structure of Bucharest proved to be fairly resilient (as most structures do). There was very little free land for new building and the little that could be identified was more often than not the object of conflicting claims of restitution. Consequently, in the first phase, investors turned to the outskirts of the city - either to agricultural land or to land provided in the nearby villages. This suited the early demand for single-family houses (a long-repressed yearning of some families) and small multi-flat buildings in so-called residential parks. This kind of supply catered for the high-end of the income scale.

After 1999, the National Housing Agency produced a limited number of units for sale at more accessible prices still targeting the upper end of middle-income groups (UN-ECE, 2000 [7]). In Bucharest the NHA's output was very small due to the lack of land owned by the municipality.

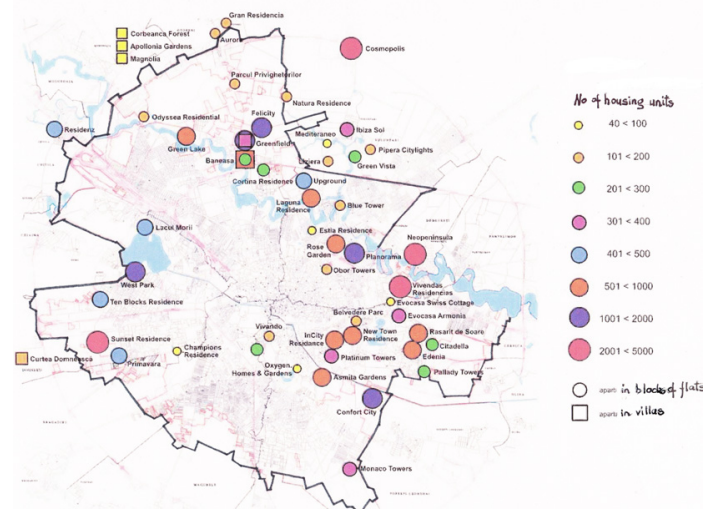

Figure 2: $\quad$ New housing units on offer (Colliers International, 2008). 
With increasing housing demand in Bucharest and available free land drying out, developers turned to brownfields. In recent years condominiums in former industrial or derelict areas have been scattered all around the city. They vary in size - from tens to several thousand apartments.

Most of the new development went to the northern part of the city outside the city boundaries, gradually pushing further to the North. New housing construction after year 2000 was disseminated on various directions without any apparent logic and relationships; it reflected the comparative advantages of cheaper land and less bureaucracy in the communes of Ilfov County. We witnessed the proliferation of a number of spaces scattered in the territory with various functions (some mixed, some exclusively for housing) that are challenging a strategic view for the development of the Municipality of Bucharest.

\subsubsection{Sub-urbanization}

As mentioned above, factors that stimulated housing construction outside Bucharest were: easily accessible and cheaper land market and large spread of prices between the capital-city and localities in the surrounding Ilfov county; the emergence of high-end housing consumers and a lesser category of families "turning back to nature". Counter to these incentives was the actual structure of Bucharest's housing stock, with over $97 \%$ in owner-occupation and still benefiting of relatively lower housing costs (despite the steep increase of utility costs).

The mere wish of families to be housed in a more attractive un-polluted environment (much advertised by the media but insufficiently documented) was not enough to trigger a widespread sub-urbanization process. As empirical analyses suggest, outward mobility (from the core-city) to the suburbia is the outcome of a great number of factors including the relationships between families and individuals, job location, amenities and services on offer and the attitudes of local authorities. In the analyzed period, we can identify two categories of families strongly motivated economically and socially to leave the city:

- The rather limited category of high-income families, filtering-up from their blocks of flats who could pay the price of an expensive single-family home; this category includes those in the 30-40 age-bracket having an above the average stable income. Empirical data show that families and individuals in this category would not give up the advantages of living in the capital-city and their option goes to apartments in high-end condominiums or refurbished flats in the central area of Bucharest, or at least in some of the newly built "residential parks" at the outskirts of the city;

- Poor families captive in the residual public stock that cannot pay the everincreasing cost of housing (maintenance, repair, utility cost). They leave the city for cheap or inherited rural housing. Housing alternative for these families would be building more social housing or providing affordable and equipped plots of land at the outskirts of the city. 
Sub-urbanization proves to be therefore a very selective segregation process (Kemeny [8]), supported by the demand and preferences of a very limited social category. So far the options of this category targeted mainly the northern part of Bucharest and further developments in Ilfov County. For the time being, migrating to some distance from Bucharest is restrained by poor services and infrastructure in rural areas. An extensive sub-urbanization though not very likely in the medium term would impact negatively on the city; if forsaken by the upper-middle class the city would be confronted with further downward-filtering in the housing stock and the administration would be faced with a substantial loss of income.

\subsubsection{Spatial segregation}

In the 1990s new types of housing aspirations and housing consumption patterns evolved generating a large process of re-considering housing spaces and the living environment. Bucharest bears witness of two types of spatial segregation reflecting the process of differentiation in the urban structure: (i) concentration of high-quality housing and (ii) the emergence of marginalized housing areas with precarious housing units and a problem-ridden living environment.

The evolution of residential areas is no more only an urban development issue but also a social and political one (Donzelot [9]). On one hand there is the concentration of "problem-populations" (unemployment, higher crime rate) generating insecurity in and around the respective areas; the above issues provide ample justification for the need of secession and for the increasing housing polarization. On the other hand urban secession is a complex social phenomenon expressing the determination of some residents to break away from the city (Jaillet [10]). Closely linked to the dilapidation of certain housing areas, spatial segregation in Bucharest can already be noticed on three levels (Donzelot [9]):

- the marginalized housing areas clearly defined in the urban structure with residents socially disintegrated;

- a certain territorial disintegration as some residents turn their back to the city and

- the relationships between the dilapidated areas and the rest of the city. These three levels create a system in which the first level of "social disintegration" in the areas with underprivileged populations and the second level of "high degree of social integration" of the upper-income families lead to the third level of social disintegration (Donzelot [9]). This is the case of the "residential parks" and of the "gated communities" built at the outskirts of the city as early signs of "secession" from the city.

Built in a speculative manner the latter are less and less attractive for the new owners. These new forms of housing failed so far to create real communities, lacking the basic amenities that forge community life. The major problem remains the difficulties to reconnect to the city due to the poor transport infrastructure.

Disenchantment with life outside the side and the increasing number of elderly families makes condominiums within the city more and more attractive. The increased demand for condominiums is an early indication for new 
preferences of housing consumption and a changed residential behaviour of families. Not a few owners of single family housing outside Bucharest turned back to the city.

A space-time perspective of the emerging spatial segregation would require taking into consideration all the factors that lead to the negative dialectics of social and spatial disintegration.

\section{Major challenges for sustainable housing}

A balanced urban development in which the development of the city-proper would be harmoniously blended with its surrounding territory would require concerted public and corporate actions (Sandu [11]).

After the collapse of the pre-1990 model of centralized decision-making and the dramatic changes in property structures, local authorities are facing new challenges in the post transition period. The Master Plan of the Municipality of Bucharest prepared in 2000 and approved by the Municipal Council of Bucharest represented a move forward by incorporating a strategic and territorial dimension in the "city project". The Master Plan has identified more land convertible for housing construction (an additional 2,000 ha) either in mixed-function areas or on individual housing plots. Changes in housing distribution within the city was contemplated by developing new mixed-function areas, reducing density in large housing estates, diversifying housing options by new land divisions for single family units, reducing rural-type housing at the peripheries.

Table 2: $\quad$ Proposed evolution of residential areas in Bucharest.

\begin{tabular}{|c|c|c|c|c|}
\hline \hline & \multicolumn{2}{|c|}{ Total area } & $\%$ of the total area of the city \\
\cline { 2 - 5 } Residential areas & $\begin{array}{c}\text { Existing } \\
\text { ha }\end{array}$ & $\begin{array}{c}\text { Proposal } \\
\text { ha }\end{array}$ & $\begin{array}{c}\text { Existing } \\
\%\end{array}$ & $\begin{array}{c}\text { Proposal } \\
\%\end{array}$ \\
\hline \hline Mixed areas & 616,12 & 2909,9 & 3,42 & 13,60 \\
\hline $\begin{array}{c}\text { Residential areas of } \\
\text { which: }\end{array}$ & 7332,39 & 7095,8 & 40,78 & 33,17 \\
\hline - traditional housing & 2333,01 & 1509,9 & 12,98 & 7,06 \\
\hline - in multi-family buildings & 2676,69 & 1897,0 & 14,89 & 8,87 \\
\hline - on urban plots & 583,03 & 3461,1 & 3,24 & 16,18 \\
\hline - on semi-rural plots & 1739,67 & 228,2 & 9,68 & 1,07 \\
\hline \hline
\end{tabular}

The relationships with the surrounding territory play a crucial role for the balanced development of the city. It is obvious that the development issues of Bucharest transcend its current administrative boundaries. These limits inherited from the pre-1989 thrifty period are much more restrained than that of other European capitals. In fact, Bucharest is already an urban agglomeration together with a number of settlements in its immediate vicinity.

It could easily be noticed that management of all the above issues are often conflicting - e.g. preservation of valuable land resources as against ensuring a diversified and attractive land supply. Other issues need a mixed approach in 
which market mechanisms be blended with the regulating powers of local authorities.

Master plans as graphic representations of future images of the city are no longer flexible enough to provide answers to the complex issues of development of Bucharest as the capital-city of the country. As the number of actors involved multiplied dramatically - including along the Municipality of Bucharest and the local governments in the surrounding territory, all the other stakeholders of a complex development - urban planning has to shift from development control to a flexible and integrated approach. It would involve cooperation, negotiation in establishing shared objectives and common projects for a real metropolitan area. Urban plans and regulations should than be completed and integrated in an institutionalized system ensuring the contribution of all stakeholders both to the planning process and to the use of resources involved.

Creating a real metropolitan area around Bucharest is subject to the capacity of Bucharest to rally all the energies of the public and private sectors, as well as the civil society in a common strategic project for the long-term (Sandu [11]). So far this proved to be a very difficult process, coming up against the reluctance of local governments. To institutionalize a real cooperation of metropolitan type would require lengthy negotiations and compromises of all parties involved. Legislation to create the metropolitan area of Bucharest has been already drafted but there is some way to go until all parties involved would reach an agreement to make it pass.

\section{Conclusions}

The spatial structure of Bucharest reflects a lengthy historic development which had been substantially altered by the pre-1990 industrialization process. The basic star-shaped structure developed around the ring-road of the city and the major access routes to the city had been judiciously conceived in the early 20th century serving as a starting point for later development. Current developments are conjectural and un-coordinated, more often than not conflicting with a harmonious development of the city in a long-term perspective. The territorial distribution of housing in and around the traditional the urban structure reflect the new relationships between housing policies on one hand and sectoral policies on the other hand, respectively the ability of the Municipal government to tackle housing issues.

The urban structure of the city did not witness dramatic alterations over the last 20 years. However, distortions in the housing system are being reflected in:

- the increasing social polarisation within the urban structure

- marginalisation of some urban areas;

- the unsustainable character of homeownership, due to the physical and asset-value decline of the existing stock, the rising cost of utilities, compounded by the still persisting earthquake risks;

- secession drives of a small category of high-income families forsaking the city towards gated communities. 
One of the main challenges facing Bucharest's housing is a failure to assess the scale and to evaluate the complexity of the above issues (UN-ECE, [7]).

Recent changes - turning back to the city of some families, a marked preference for condominiums within the city - reflect a certain trend that cannot be extrapolated for the long-term. The financial downturn is expected to putting an end to a volatile, highly-speculative real estate market, to the artificial high prices of obsolete, often dilapidated housing. Meanwhile, it would presumably impact on the behaviour of both housing consumers and developers. This is also a propitious time for reflection and evaluation, raising the awareness of the links between housing policies and urban development in general and the creation of the metropolitan area of Bucharest in particular.

Relationships between housing policies and urban development patterns are in the focus of amendments made to the housing legislation and institutional framework. The new draft Housing Law aims to strengthen the role of local authorities in formulating Local Housing Programs. The LHPs would formulate a coherent diagnosis of the existing housing situation and define the objectives and priorities that would ensure a balanced distribution of a diversified housing supply. The quality of the diagnosis would be a crucial part of the LHP, closely linked to the territorial development of the city and based on a large consultation of all parties interested and favouring social-mix in housing.

Meanwhile a bill has been drafted for the institutionalization of the Metropolitan Area of Bucharest. MAB would be an inter-community development association, of public interest and governed by private law, with a board including representatives of the Municipality of Bucharest and its districts and of each administrative unit of Ilfov County. The major aim of the MAB would be to coordinate the use of resources and to harmonise the development objectives of the whole territory along common priorities. Both measures are expected to enhance the quality of residential dynamics articulated with the subsequent urban development plans.

\section{References}

[1] Lascu, N. Evolutia urbanistica a Bucurestiului. Plan urbanistic general al Municipiului Bucuresti, faza 2, 1998.

[2] Lujanen, M., How useful are housing indicators as a tool for housing policy in Europe?. The Netherlands Journal of Housing and Built Environment, Special issue, vol.8, no 1, 1993.

[3] Kemeny, J. The myth of homeownership. Routledge and Kegan Paul, 1981

[4] Tsenkova, S. Housing in Transition and Transition in Housing: The Experience of Central and Eastern Europe. Kapital Reklama, Sofia, 2000

[5] Budisteanu, I. The long-lasting impacts of earlier housing policies (pp. 221237). Housing Finance - New and Old Models, ed. Hegedus, J., Struyk, R. Open Society Institute, Budapest, 2005.

[6] Turner, B., Hegedus, J., Tosics, I. (eds) The reform of Housing in Eastern Europe and the Soviet Union. Routledge, London, 1992.

[7] UN-ECE Country Profile of the Housing Sector, Geneva, 2000. 
[8] Kemeny, J. Housing and social theory, Routledge, London, 1992.

[9] Donzelot, J. De la sécéssion chez les modernes. Proc. of the seminar, in "La nouvelle question urbaine », Ministère de l'équipement, des Transport et du Logement, 1999/2000.

[10] Jaillet, M. Ch., Peut-on parler de récession urbaine à propos des villes européennes? Proc. of the seminar, in "La nouvelle question urbaine ", Ministère de l'équipement, des Transport et du Logement, 1999/2000.

[11] Sandu, A., Un program pentru o metropola. Arhitext Design, 1/2000. 